DOI: 10.33310/2518-7813-2019-66-3-244-248

УдК 37.09

\title{
Мухіддін ХАЙРУДДІнов
}

доктор педагогічних наук,

професор кафедри педагогіки та інклюзивної освіти

Миколаївського національного університету імені В.О.Сухомлинського

\section{РЕАЛІЗАЦІЯ НАСТУПНОСТІ СУМІСНОЇ ДІЯЛЬНОСТІ ЗАКЛАДІВ ДОШКІЛЬНОЇ ОСВІТИ І ПОЧАТКОВОЇ ШКОЛИ З ФОРМУВАННЯ ГОТОВНОСТІ ДО ШКІЛЬНОГО НАВЧАННЯ}

\begin{abstract}
У статті розглядається проблема забезпечення наступності дошкільної та початкової освіти. Від змістовності і наступності процесу психолого-педагогічного супроводу дитини на ранніх етапах їі розвитку залежить успішність ї̈ навчання та соціалізації в цілому. Наступність в освіті, що декларується в концептуальних і нормативних документах, інколи не знаходить практичної реалізації в діяльності освітніх організацій та закладів. Освітнє середовище й освітні практики закладів дошкільної та початкової освіти, як правило, не співпадають з широко відомими теоретичними положеннями про наступність і неперервність освітнього процесу. Необхідна організація сумісної роботи спеціалістів загальноосвітньої школи та закладів дошкільної освіти з науково-педагогічного супроводу розвитку цих процесів. Автор звертає увагу на сутність поняття «наступність» у контексті неперервної освіти дітей дошкільного та початкового шкільного віку. Представлено підстави, компоненти та засоби забезпечення наступності дошкільної та початкової освіти. Обумовлюється необхідність науково-педагогічного супроводу діяльності педагогічних колективів освітніх закладів зі створення єдиного освітнього простору загальноосвітньої школи та закладу дошкільної освіти. Розкриваються організаційно-педагогічні умови реалізації принципу наступності в навчально-виховній діяльності початкової школи та закладу дошкільної освіти.

Ключові слова: наступність, готовність до школи, заклад дошкільної освіти, початкова школа, співпраця, взаємодія, зміст, дитина, батьки, педагог.
\end{abstract}

Підготовка дітей до школи є важливим педагогічним завданням закладів дошкільної освіти. Особливе значення в умовах продовження модернізації української освіти набуває проблема наступності дошкільної та початкової освіти, стрижнем якої виступає готовність дітей до навчання в школі.

Пунктом 1 статті 4 Закону України «Про дошкільну освіту» визначено, що дошкільна освіта $€$ обов'язковою первинною складовою частиною безперервної освіти в Україні. Аналогічна норма присутня в нормативних документах переважної більшості розвинених держав, є вимогою для країн ЄC і грунтується на багаторічному досвіді та численних висновках фахівців різних профілів (психологів, педагогів, медиків тощо).

У педагогічній теорії наступність трактується як універсальна педагогічна категорія, що забезпечує взаємоузгодженість і взаємозв'язок суміжних ступенів, етапів педагогічної діяльності і стверджує безперервність системи освіти (М. Вашуленко), загальнодидактичний принцип (А. Бушля, Ш. Ганелін, В. Загвязинский, Н. Посталюк), умови забезпечення ефективності навчально-виховного процесу (В. Онушкін), Загально педагогічну закономірність (Ю. Кустов), принцип безперервної освіти (С. Годнік). Методологічні аспекти наступності досліджують А. Антонов, Є. Баллер, Л. Депенчук, С. Колесников,
C. Мукашев, I. Огородник. Безпосередньо до вивчення проблеми наступності між дошкільною та початковою ланками освіти звертаються Л. Артемова, Г. Бєлєнька, А. Богуш, К. Волинець, Ю. Волинець, Т. Гущина, О. Кононко, Т. Поніманська.

Що ж ми вкладаємо в це поняття? Під наступністю ми розуміємо послідовний перехід від одного ступеня освіти до іншого, що виявляється у збереженні і поступову зміну змісту, форм, методів, технологій навчання і виховання.

Наведемо філософське визначення поняття наступності. Наступність - об'єктивний необхідний зв'язок між новим і старим у процесі розвитку, одна з найбільш істотних рис закону заперечення [2, 327].

Діалектично зрозуміле заперечення передбачає не тільки ліквідацію старого, але й збереження та подальший розвиток того прогресивного, раціонального, що було досягнуто на попередніх щаблях, без чого неможливий рух вперед ні в бутті, ні в пізнанні [2, 330].

Наступність - це не тільки підготовка до нового, але, що ще більш важливо і суттєво, збереження і розвиток необхідного і доцільного старого, зв'язок між новим і старим як основа поступального розвитку процесу.

Як педагогічний феномен спадкоємність має складну структуру, яка охоплює наступність у змісті, формах, методах навчання і виховання, 
а також у педагогічних вимогах і умовах. Зміст $\epsilon$ домінуючим фактором у навчанні і вихованні дітей. У більшості навчальних дисциплін початкової освіти провідним компонентом змісту є застосування певних способів діяльності, спрямованих на оволодіння молодшими школярами широким колом різноманітних умінь і навичок. Однак всі вони базуються на усвідомлених протягом попереднього (дошкільного) періоду знаннях про те, чому і як їх треба виконувати $[3,39]$.

Як зазначає 0. Савченко, «наступність у роботі закладу дошкільної освіти і початкової школи це не тільки традиційна наступність у змісті, методах, формах і прийомах, перш за все бачення i реалізація наступності в лініях, основних аспектах розвитку особистості дошкільника і молодшого школяра». Завдання дошкільної та початкової освіти полягає в тому, щоб, дотримуючись принципу наступності, допомогти формуванню в дитини орієнтовної основи, яку вона може і повинна використовувати в різних видах своєї пізнавальної та продуктивної діяльності $[3,40]$.

Сьогодні поняття наступності практикується широко - як безперервний процес виховання i навчання дитини, що має спільні та специфічні цілі для кожного вікового періоду.

Наступність виступає одним із головних завдань закладу дошкільної освіти і школи, як необхідна умова адаптації першокласників до нового виду навчальної діяльності.

Школа і заклад дошкільної освіти розглядаються нами як дві суміжні ланки в системі освіти. Непідготовленість дитини до нового соціальним статусом тягне за собою негативні наслідки: в класі вона відчуває дискомфорт, тому що тут змінюється ії соціальна позиція, дитина включається в особливий режим. Тому в навчально-виховній роботі школи і будь-якого дошкільного закладу, що забезпечує необхідну підготовку дітей до навчання в школі, повинна існувати наступність.

Варто зауважити, що наступність між дошкільним і шкільним ступенями освіти не повинна розумітися тільки як підготовка дітей до навчання. Щоб зробити перехід дітей до школи більш м'яким, вчителям необхідно познайомитися 3 формами і методами роботи в дошкільному закладі, допомогти першокласникам швидше адаптуватися до нових умов.

Як у дошкільному навчанні, так і в школі, освітньо-виховний процес повинен бути підпорядкований становленню особистості дитини: розвитку його компетентності (комунікативної, фізичної), самостійності, відповідальності, самосвідомості і самооцінки, свободи і безпеки поведінки.

Процес наступності можна розглядати з двох сторін:
- на дошкільному ступені освіти зберігається самоцінність дошкільного дитинства і формуються фундаментальні особистісні якості дитини, що служать основою успішного шкільного навчання;

- школа як послідовник дошкільного ступеню освіти не починає свою роботу з нуля, а підхоплює досягнення дошкільника й організовує педагогічну практику, розвиваючи таким чином накопичений ним потенціал.

Таке розуміння наступності дозволяє реально здійснювати безперервність у розвитку і навчанні дітей, а саме:

а) координувати мету, завдання, зміст, методи, засоби і форми організації освітніх процесів закладів дошкільної освіти і школи;

б) забезпечувати умови, спрямовані на збереження здоров'я, емоційного благополуччя і на розвиток індивідуальності кожної дитини.

При визначенні провідних ідей у ході реалізації наступності необхідно виділити пріоритети у змісті освіти на кожному етапі вікового розвитку дитини з урахуванням сучасної соціальної ситуації, не допускати поспіху і дублювання змісту наступної ланки освіти.

Єдині теоретичні основи, принципи організації освітньої роботи з дітьми, наступність і узгодженість цілей, завдань, методів, засобів, форм організації виховання і навчання, що забезпечують ефективний поступальний розвиток дитини, $\epsilon$ основою для реалізації на практиці вирішення проблеми наступності.

Необхідно зауважити, що в освітньому процесі використовуються єдині форми роботи: спільна діяльність дітей, спільна діяльність дорослого і дітей, самостійна діяльність

Пріоритетною формою організації та проведення занять з дітьми-дошкільнятами є гра - провідний у цьому віці вид діяльності, що створює найбільш сприятливі умови для психічного та особистісного розвитку дитини, оскільки в процесі гри вона сама прагне навчитися тому, що ще не вміє. Вся робота з дітьми дошкільного і молодшого шкільного віку повинна виходити з принципу «не нашкодь» і бути спрямованою на збереження здоров'я, емоційного благополуччя і розвитку індивідуальності кожної дитини. Тільки в рамках розвиненої ігрової діяльності в дітей формуються початку діяльності навчальної.

Розвиток навичок пізнавальної діяльності найбільш ефективно проходить у період дошкільного дитинства. Навчання в дошкільному закладі - складова частина педагогічного процесу, спрямованого на всебічний розвиток і виховання дитини-дошкільника. Він, як і в школі, являє 
собою цілеспрямований і організований процес формування знань, навичок і умінь, виховання відносин, навичок і звичок поведінки, побудований на основі принципів дидактики, має чітку програму, протікає у спеціально створених умовах, з використанням спеціальних методів і прийомів.

На протязі дошкільного етапу дитина повинна засвоїти певний обсяг знань, умінь і навичок. Знання є результатом пізнавальної діяльності, і тому їх характер визначається характером пізнання дошкільнят.

Існують, як відзначав С. Рубінштейн, два види навчання, в результаті яких людина опановує нові знання і вміння. «Один із них спеціально спрямований на оволодіння цими знаннями і вміннями як на свою пряму мету. Інший призводить до оволодіння цими знаннями і вміннями, здійснюючи інші цілі».

Для дітей дошкільного віку другий вид навчання дуже характерний: вони набувають знання в грі, праці та інших видах діяльності $[4,335]$.

Інтелектуальні запити старших дітей виражаються і в тому, що їх вже не приваблюють прості ігри та іграшки. У них розвивається інтерес до набуття знань і умінь не тільки для застосування в даний час, але і про запас. Підвищується допитливість, інтерес до знань і розумової діяльності, з'являється вимогливість до себе та інших. Навчальна діяльність у старших дошкільників яскраво виділяється з-поміж інших видів діяльності, передбачає цілеспрямоване навчання дітей і засвоєння ними певних знань, умінь і навичок. На основі цього багажу дитина здатна вирішувати різні пізнавальні завдання. Ці вміння є найважливішим критерієм успішності навчальної діяльності дітей і маю бути сформовані до кінця дошкільного дитинства $[5,89]$.

Перехід від ігрової до навчальної діяльності не відбувається миттєво. Це тривалий і напружений процес, що вимагає від дитини вольових зусиль. Для того, щоб допомогти в подоланні цього складного адаптаційного періоду, необхідно створити звичні для дитини умови.

У дошкільному віці формуються лише передумови навчальних дій, які знаходять свій розвиток на початковому ступені освіти.

У дошкільнят у закладах дошкільної освіти формуються такі елементи навчальної діяльності як: здатність діяти за зразком; вміння слухати i виконувати інструкцію; вміння працювати зосереджено й виконувати завдання до кінця; уміння ставити і відповідати на запитання; вміння оцінювати як свою роботу, так і роботу інших дітей.

Тим самим у дітей формується психологічна готовність до шкільного навчання. Підготовка дітей до школи - завдання комплексне, багатогранне і охоплює всі сфери життя дитини.

Згідно з численними дослідженнями педагогів-психологів «правильна» підготовка повинна бути зосереджена на ігровий діяльності, фізичному, фізіологічному і психологічному розвитку дошкільника. Фізіологами доведено, що розвиток дрібної моторики активізує розвиток мовного центру. У дошкільному віці дитині корисно ліпити, складати композиції з дрібних частин, конструювати, розфарбовувати олівцями. Не менш важливо виробляти вміння слухати, говорити.

Тому провідною метою підготовки до школи має бути формування в дошкільника якостей, необхідних для оволодіння навчальною діяльністю, допитливості, ініціативності, самостійності, довільності, творчого самовираження дитини тощо.

Одним із найважливіших завдань, що вимагає комплексного рішення, є створення єдиного освітнього процесу, що зв'язує дошкільні та шкільні роки. Нами визначено три основних напрямки забезпечення наступності між дошкільною та шкільною освітою: методична робота, робота 3 батьками, робота з дітьми.

Важливою умовою досягнення високого рівня співпраці дошкільної та початкової освіти $\epsilon$ забезпечення безперервності освіти, яке розуміється як узгодженість, наступність всіх компонентів освітньої системи (цілей, завдань, змісту, методів, засобів, форм організації виховання і навчання) на кожному ступені освіти. Наступність, яка сприяє збереженню і зміцненню здоров'я дитини, веде до успішної адаптації дітей. Успіхи у шкільному навчанні багато в чому залежать від якості знань і умінь, сформованих в дошкільному дитинстві, і перспективності підвищення якості освіти в цілісній системі освіти.

Наступність є двостороннім процесом, в якому на дошкільному ступені освіти зберігається самоцінність дитини і формуються її фундаментальні особистісні якості - ті досягнення, які служать основою для успішного навчання в школі.

Наступність 3 позиції школи - це опора на ті знання, навички та вміння, які $\epsilon$ в дитини, пройдене осмислюється на більш високому рівні. Організація роботи в школі повинна відбуватися з урахуванням дошкільного понятійного і операційного рівня розвитку дитини.

Наступність $з$ точки зору ДНЗ - це орієнтація на вимоги школи, формування тих знань, умінь і навичок, які необхідні для подальшого навчання в школі.

Однак, підготовка до школи часто розглядається як більш раннє вивчення програми першого класу і зводиться до формування вузько предметних знань і умінь. У цьому випадку спадкоємність 
між дошкільним і молодшим шкільним віком визначається не тим, чи розвинені в майбутнього школяра якості, необхідні для здійснення нової навчальної діяльності, сформовані чи ії̈ передумови, а наявністю або відсутністю в нього певних знань 3 навчальних предметів.

Таким чином, готовність до школи виступає як інтегральна характеристика новоутворень соціально-особистісного розвитку дошкільника, представляючи складну структурну єдність ряду взаємопов'язаних компонентів мотиваційного, комунікативного, емоційно-вольового, фізичного й інтелектуального характеру.

«Готовність до школи» - необхідний і достатній рівень психічного (особистісного, інтелектуального) й фізичного розвитку дитини для успішного освоєння основних загальноосвітніх програм початкової освіти.

Співпраця вихователя й учителя полягає у вивченні та аналізі програм початкової школи і дошкільного закладу, нормативних документів 3 підготовки дітей до школи, в обміні досвідом, в рекомендаціях учителя вихователю з підготовки дітей до школи.

У дітей різні індивідуальні можливості і здібності, тому цілком закономірно, що в них різний рівень підготовки. Проблема полягає в тому, що підхід учителів і батьків до поняття «готовність до школи» різниться. Батьки вважають, що якщо вони навчать дітей рахувати й писати до школи, то це і буде запорукою їх успішного навчання.

Психологічна готовність включає наступні компоненти: мотивація до навчання (в дитини має бути бажання йти в школу); сформованість соціальної позиції школяра; достатній для шкільного навчання рівень розумового розвитку (він $є$ основою для успішного оволодіння шкільними знаннями, уміннями і навичками, а також для підтримки оптимального темпу інтелектуальної діяльності, щоб дитина встигала працювати разом із класом).

3 того часу, як у свідомості дитини уявлення про школу набуло рис шуканого способу, тобто систему власних потреб і прагнень дитини, пов'язаних зі школою, можна судити про початковий рівень готовності дитини до школи (нове ставлення до школи, «Хочу в школу»).

Спеціальна готовність передбачає готовність дитини до освоєння читання і письма. Загальна i спеціальна готовність до школи між собою взаємопов'язані і взаємозумовлені.

Визначення готовності до школи проводиться в першу чергу за допомогою психолога і тестів, що дозволяють виявити особливості мовлення, логічне мислення і розуміння соціальних відносин. Другий - визначення розвитку дрібної моторики. Дитина обов'язково повинен знати відомості про себе і про свою родину - це визначає рівень його розвитку і загальне соціальне орієнтування.
Потрібно приділяти увагу мовному розвитку, вмінню висловлювати свої думки і словниковий запас: чи здатна дитина відокремити предмет або явище від самого слова?

Важливо звернути увагу на працездатність дошкільника. Чи може дитина бути посидючою, уважною? Чи швидко втомлюється і втрачає інтерес до початої? Чи добре запам'ятовує? Часто дитина не може реалізувати свій інтелектуальний і творчий потенціал саме через проблеми в цій сфері.

Від дитини потрібно вміння дружити, ладити, визнавати авторитет старших і здатність постояти за себе, не завдаючи шкоди іншому. Було б чудово, якби вчителька приділяла увагу і час для того, щоб здружити дітей. I, звичайно, дитині знадобиться хороше фізичне здоров'я та ін.

Ми виділяємо дві підструктури: готовність до навчальної діяльності та соціально-психологічну готовність дитини до школи (готовність до взаємодії з новим соціальним оточенням, виконання шкільних норм і правил поведінки, тобто готовність до нової соціальної ролі «учень»).

В якості критеріїв підготовленості дитини до школи можна прийняти такі показники: нормальний фізичний розвиток і координація рухів; бажання навчатися; управління своєю поведінкою; володіння прийомами розумової діяльності; прояв самостійності; ставлення до однолітків і дорослих; ставлення до праці; вміння орієнтуватися в освітньому просторі.

Школа і дошкільний заклад - дві суміжні ланки в системі освіти. Найважливіше завдання освіти і її основний результат - це спадкоємність, що створює загальний сприятливий фон для фізичного, емоційного та інтелектуального розвитку дитини в закладі дошкільної освіти і початковій школі, що передбачає комплексне вирішення завдань освіти і створення єдиного освітнього процесу, що зв'язує дошкільні та шкільні роки дітей.

Ефективному переходу дітей із дошкільного закладу в початкову школу сприяє самостійність, вміння дітей справлятися з самообслуговуванням, готовності діяти без допомоги дорослого. Освітньо-виховний процес повинен бути підпорядкований становленню особистості дитини: розвитку їі компетентності (комунікативної, фізичної), відповідальності, самосвідомості і самооцінки, свободи і безпеки поведінки. Важливо забезпечити збереження самоцінності дошкільного віку, коли закладаються найважливіші риси майбутньої особистості. Слід формувати соціальні уміння і навички майбутнього школяра, необхідні для благополучної адаптації до школи. Необхідно прагнути до організації єдиного розвиваючого світу дошкільної та початкової освіти. Це означає, що сьогодні школа повинна вибудовувати свою роботу на досягненнях дошкільника, організовувати навчальну діяльність з урахуванням накопиченого 
досвіду дітей, оскільки освітня діяльність початкової освіти має бути спрямована на формування предметно-розвивального середовища і розвиток тих якостей особистості дошкільнят, які визначають розвиток стійкого пізнавального інтересу й успішного навчання у школі.

\section{Список використаних джерел}

1. Дошкольное образование теперь является обязательным?| http://doshkolenok.kiev.ua

2. Философский словарь. М., 1975. С.327.)

3. Савченко, О. Я. Дидактика початкової школи : підруч. для студентів пед. Фак .Київ : Абрис, 1997. 416 с

4. Рубинштейн С.Л. основі общей психологи: в 2-х т./ Академия пед..наук СССР. М., Педагогика. 1989. (Труді членов корреспондентов и действительніх членов Академии пед..наук СССР). Т1 / [Сост. К. А Абульханова-Славская, А. В. Брушлинский]/1989/.485 с.

5. Усова А.П. Обучение в детском саду. М.: Просвещение, 1981. 176 с.

\section{References}

1. Doshkolnoe obrazovanye teper yavliaetsia obiazatelnыm?| http://doshkolenok.kiev.ua

2. Fylosofskyi slovar. M., 1975. S.327.)

3. Savchenko, 0. Ya. Dydaktyka pochatkovoi shkoly : pidruch. dlia studentiv ped. fak. / O. Ya. Savchenko. - Kyiv : Abrys, 1997. - $416 \mathrm{~s}$

4. Rubynshtein S.L. osnovi obshchei psykholohy: v 2-kh t./ Akademyia ped..nauk SSSR. - M., Pedahohyka. 1989. - (Trudi chlenov korrespondentov y deistvytelnikh chlenov Akademyy ped..nauk SSSR). T1 / [Sost. K. A Abulkhanova-Slavskaia, A. V. Brushlynskyi]/1989/- $485 \mathrm{~s}$.

5. Usova A.P. Obuchenye v detskom sadu. M.: Prosveshchenye, 1981. - $176 \mathrm{~s}$.

Мухиддин Хайруддинов. Реализация преемственности совместной деятельности учреждений дошкольного образованя и начальной школы по формированию готовности к школьному обучению

В статье рассматривается проблема обеспечения преемственности дошкольного и начального образования. От содержательности и преемственности процесса психолого-педагогического сопровождения ребенка на ранних этапах его развития зависит успешность его обучения и социализации в целом. Декларируемая в концептуальных и нормативных документах преемственность в образовании нередко не находит практической реализации в деятельности образовательных организаций и учреждений. Образовательная среда и образовательные практики учреждений дошкольного и начального образования, как правило, рассогласованы с широко известными теоретическими положениями о преемственности и непрерывности образовательного процесса. Необходима организация совместной работы специалистов общеобразовательной школы и детских дошкольных образовательных учреждений по научнопедагогическому сопровождению развития этих процессов. Автор обращает внимание на сущность понятия «преемственность» в контексте непрерывного образования детей дошкольного и младшего школьного возраста. Представлены основания, компоненты и средства обеспечения преемственности дошкольного и начального образования. Обосновывается необходимость научно-педагогического сопровождения деятельности педагогических коллективов образовательных учреждений по созданию единого образовательного пространства общеобразовательной школы и учреждений дошкольного образования. Раскрываются организационно-педагогические условия реализации принципа преемственности в учебно-воспитательной деятельности начальной школы и детского сада.

Ключевые слова: преемственность, готовность к школе, дошкольное образовательное учреждение, начальная школа, сотрудничество, взаимодействие, содержание, ребенок, родители, педагог.

Mukhiddin Khairuddinov. Mplementation of pre-administration of joint activity of doo and advanced school on formation of preparedness to school education

In article the problem of ensuring continuity of preschool, primary education is considered. The success of its training and socialization in general depends on pithiness and continuity of process of psychology and pedagogical escort of the child at early stages of his development. The continuity declared in conceptual and normative documents in education quite often does not find implementation in activity of the educational organizations and institutions. The educational environment and educational practicians of institutions of preschool and primary education, as a rule, rassoglasovana with widely known theoretical regulations on continuity and the continuity of educational process. The organization of collaboration of specialists of comprehensive school and children's preschool educational institutions for scientific and pedagogical maintenance of development of these processes is necessary. The author pays attention to essence of the concept "continuity" in the context of continuous education of children of preschool and younger school age. The bases, components and means of ensuring of continuity of preschool and primary education are presented. Need of scientific and pedagogical maintenance of activities of pedagogical staff of educational institutions for creation of uniform educational space of comprehensive school and institutions of preschool education is proved. The author pays attention to essence of the concept "continuity" in the context of continuous education of children of preschool and younger school age. Organizational and pedagogical conditions of realization of the principle of continuity in teaching and educational activity of elementary school and kindergarten reveal.

Klyuchy words: continuity, readiness for school, preschool educational institution, elementary school cooperation, interaction, maintenance, child, parents, teacher. 